\title{
Radiation-induced expression of platelet endothelial cell adhesion molecule-1 in cerebral endothelial cells
}

\author{
B. Chen ${ }^{1,2}$, Z. Zhao $^{1 *}$, N. Raoufi-Rad ${ }^{1}$, V. Lee ${ }^{1}$, M. Grace 3 , R. Reddy',2, \\ M. Stoodley ${ }^{1}$
}

\begin{abstract}
${ }^{1}$ Faculty of Medicine and Health Sciences, Macquarie University, New South Wales, Australia ${ }^{2}$ Faculty of Medicine, University of New South Wales, Kensington, New South Wales, Australia ${ }^{3}$ Genesis Cancer Care, Macquarie University Hospital, Sydney, NSW, Australia
\end{abstract}

\section{- Original article}

\author{
*Corresponding author: \\ Dr. Zhenjun Zhao, \\ Fax: +61298123600 \\ E-mail: \\ zhenjun.zhao@mq.edu.au \\ Revised: Sept. 2015 \\ Accepted: Nov. 2015 \\ Int. J. Radiat. Res., July 2016; \\ 14(3): 181-188 \\ DOI: 10.18869/acadpub.ijrr.14.3.181
}

\begin{abstract}
Background: Radiation-induced molecular changes on the endothelial surface of brain arteriovenous malformations (AVM) may be used as markers for specific vascular targeting agents. In this study, we examined the level of expression of platelet endothelial cell adhesion molecule-1 (PECAM-1) on brain endothelial cell surface after radiation treatment, with the aim of targeting the radiation-induced PECAM-1 on the AVM endothelium with prothrombotic agents to selectively occlude AVM vessels. Materials and Methods: Mouse cerebral endothelial cells (bEnd.3) were irradiated with 5, 15 , or 25 Gy. Real-time quantitative polymerase chain reaction (PCR) and incell enzyme-linked immunosorbent assay (ELISA) were performed to quantify the temporal gene and surface PECAM-1 protein expression up to 168 hours post-irradiation. Two-tailed unpaired t-tests were used to determine statistical significance. Results: PECAM-1 gene expression was found to be significantly elevated post-irradiation in real-time quantitative PCR, with the maximum level of gene expression being evident at 120 hours post-irradiation representing an 11-fold increase in comparison to non-irradiated controls $(p<0.001)$. In-cell ELISA detected a similar up-regulation for protein expression on the cell surface with delayed peak time. Conclusion: Ionising radiation can induce the up-regulation of PECAM-1 on brain endothelial cell surface. This protein may be a potential candidate for facilitating selective AVM vessel occlusion through the application of radiosurgery followed by vascular targeting.
\end{abstract}

Keywords: Arteriovenous malformations (AVM), platelet endothelial cell adhesion molecule-1 (PECAM-1), radiation, cerebral endothelial cells.

\section{INTRODUCTION}

The effect of ionising radiation on cells is well -documented $(1,2)$. It can cause direct cellular damage through the modification of macromolecules such as deoxyribonucleic acid (DNA) and proteins, and indirect cellular damage through the production of reactive oxidative species (3). Cells respond to damages through a variety of mechanisms including cell cycle arrest, DNA repair, senescence and apoptosis $^{(4)}$. These events involve many biochemical processes which are likely to alter the surface molecular composition of cells.

Ionising radiation has been used for the treatment of diseases for many years. However, utilising the molecular changes induced by radiation to enhance the efficacy of biological treatments has not attracted much attention until recently(5). With the advent of stereotactic radiosurgery techniques, radiation can now be delivered to a targeted volume with $<1 \mathrm{~mm}$ accuracy $(6,7)$. This means molecular changes are limited to the target tissue. These radiationinduced molecular changes/markers may be used as targets to deliver specific treatment 
agents to the irradiated area selectively. For this purpose, the markers on the endothelial surface are of particular interest considering intravascular therapeutic agents have direct access to these markers. Furthermore, endothelial cells have been demonstrated to be very sensitive to radiation (8). Our interest is to use this strategy to treat cerebral arteriovenous malformations (AVM) ${ }^{(9)}$.

AVMs are congenital vascular abnormalities that are the most common cause of intracerebral haemorrhage in children and young adults $(10,11)$. AVMs comprise feeding arteries, a conglomeration of vessels known as a nidus, and one or more draining veins ${ }^{(12)}$. Arteriovenous shunting exposes draining veins to arterial pressure, predisposing them to haemorrhage ${ }^{(10}$, 13,14). AVM haemorrhageis associated with an approximately $20 \%$ mortality rate and $30 \%$ disability rate(15-17).

The aim of AVM treatment is to prevent haemorrhage by obliterating or removing the AVM nidus. Unfortunately, over one-third of AVMs are untreatable using the conventional modalities of microsurgery, embolization and radiosurgery(18-20). Microsurgery carries a high rate of perioperative death or disability for AVMs that are large, adjacent to eloquent brain regions, and with deep venous drainage or deep perforating arterial supply(19-21). Embolization leads to a low rate of complete obliteration when used as the sole treatment and is therefore usually only an adjunct to surgery or radiosurgery(19, 22-25). Radiosurgery offers a steep drop-off in radiation dose to the tissue surrounding the target area which cannot be

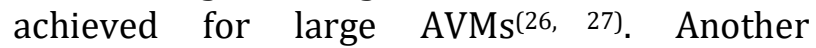
disadvantage of radiosurgery is the $2-3$ year delay to complete obliteration, during which time the AVM poses a haemorrhage risk ${ }^{(26,28-32)}$.

Vascular targeting is a technique whereby pro-thrombotic agents are introduced intravascularly to selectively bind to the endothelium within an abnormal tissue to block the blood flow. The potential use of vascular targeting in AVM treatment through induction of selective thrombosis and vessel occlusion is theoretically feasible by exploiting molecular differences between normal and abnormal endothelium(33). However, inherent molecular differences between AVM and normal cerebral vessels are unlikely to grant adequate discrimination for selective vascular targeting(3437). Radiation-induced markers should overcome this hurdle. Ideally these molecules should have adequate discrimination power so that vascular targeting agents (such as a conjugate of the relevant antibody and a thrombotic agent) will predominately bind/accumulate in the irradiated tissues.

PECAM-1 has been documented to be upregulated on human umbilical vein endothelial cells, pulmonary endothelial cells, and bone marrow cell lines when exposed to subclinical doses of radiation ${ }^{(38-41)}$. It is a cell-cell adhesion glycoprotein constitutively expressed at the lateral junction of endothelial cells, platelets and circulating leukocytes, and is involved in a plethora of cell adhesion processes ${ }^{(42-45)}$. PECAM -1 's role in maintaining the structural integrity of the endothelial cell layer, and its luminal location on the AVM endothelium, makes it a potential vascular target $(35,46,47)$. In this study, we measured the temporal expression of PECAM -1 following irradiation with 5, 15, and 25 Gy in cultured endothelial cells to elucidate its suitability as a marker for vascular targeting in AVM treatment.

\section{MATERIALS AND METHODS}

\section{Cell culture and irradiation}

Immortalised mouse cerebral endothelial cells (bEnd.3) (ATCC, Manassas, VA, USA) were cultured in complete Dulbecco's Modified Eagle Medium (DMEM) (Sigma-Aldrich, St. Louis, MO, USA) supplemented with $10 \%$ foetal bovine serum (Fisher Biotech, Wembley WA, Australia) and $1 \%$ penicillin/streptomycin (Gibco, Mulgrave, Vic, Australia). Cells were seeded into T75 flasks for ribonucleic acid (RNA) extraction and 96-well microplates for in-cell enzymelinked immunosorbent assay (ELISA). Cells were grown at $37^{\circ} \mathrm{C}$ in a humidified environment with $5 \% \mathrm{CO}_{2} /$ air. 
Cells were irradiated using x-ray via a Linear Accelerator (LINAC, Elekta AB, Stockholm, Sweden) with a single dose of 5, 15 or $25 \mathrm{~Gy}$. The rationale of selecting these 3 dose levels is based on the fact that 25 Gy is generally the radiation dose used in clinic to treat AVM patients and we would like to find out whether or not lower doses can induce similar molecular changes on the endothelial surface. The LINAC is calibrated according to the international standard of dosimeter (TRS398). Additionally, it has been audited regularly by the Australian radiation protection and nuclear safety agency (ARPANSA). In vivo film dosimetry was performed which confirmed that the planned radiation dose was actually delivered. The cell confluences of the flasks and plates at the time of irradiation were $50 \%$ and $30 \%$ respectively. Control samples were not irradiated.

\section{RNA extraction and quantification}

RNeasy Mini Kit (Qiagen, Frederick, MD, USA) was used to extract RNA from both control and irradiated bEnd. 3 cells at 1, 24, 72, 120 and 168 $\mathrm{h}$ post-irradiation. Cells were harvested by trypsinisation. The samples were subsequently transferred into $15 \mathrm{~mL}$ RNase-free centrifuge tubes and spun for $5 \mathrm{~min}$ at $1200 \mathrm{rpm}$. The resultant cell pellet was resuspended in lysis buffer and homogenised using a 20-gauge syringe. Following the addition of $70 \%$ ethanol to the homogenised lysate, purification of RNA was performed via centrifugation in a RNeasy Mini spin column for $15 \mathrm{sec}$ at $15000 \mathrm{rcf}$. The column was washed and the resultant RNA was eluted in RNase-free water. Elimination of genomic DNA contamination was performed using the RNase-Free DNase Set (Qiagen). Final RNA concentration was measured using a NanoDrop 2000 Spectrophotometer (Thermo Fischer Scientific, Waltham, MA, USA).

\section{Reverse transcription}

One $\mu \mathrm{g} / \mu \mathrm{L}$ of RNA solution (normalised concentration) was reverse transcribed in $20 \mu \mathrm{L}$ reactions using the Tetro cDNA Synthesis Kit (Bioline, Alexandria, NSW, Australia) according to the manufacturer's instructions on the Flex Cycler (Analytikjena, Jena, Germany). Samples were annealed at $25^{\circ} \mathrm{C}$ for $5 \mathrm{~min}$, then incubated at $42^{\circ} \mathrm{C}$ for $45 \mathrm{~min}$, followed by $95^{\circ} \mathrm{C}$ for $5 \mathrm{~min}$ to inactivate the reverse transcriptase. The cDNA was used immediately for real-time quantitative PCR reactions or stored at $-20^{\circ} \mathrm{C}$ for later use.

\section{Primer validation}

The specificities of the house-keeping genes (HKG) and the target gene, PECAM-1, were tested by running an agarose gel electrophoresis on quantitative PCR end-products. Mouse PECAM-1 primer (Qiagen) was purchased commercially with a guaranteed efficiency of 90 - $110 \%$. The efficiency of the house-keeping genes (GeneWorks, Thebarton, SA, Australia) was tested previously by running a real-time quantitative PCR with varying concentrations of cDNA. House-keeping genes' sequences are displayed in table 1 .

\section{Real-time quantitative PCR}

Real-time quantitative PCR was performed on the three groups receiving different radiation doses of 5, 15, 25 Gy ( $=12)$. Non-irradiated cells were used as controls. Real-time quantitative PCR amplification and analyses were completed using ViiA7 (Life Technologies, Mulgrave, Vic, Australia) with SYBR green detection and the default thermocycler program: $20 \mathrm{sec}$ of pre-incubation at $95^{\circ} \mathrm{C}$, followed by 40 cycles for $1 \mathrm{sec}$ at $95^{\circ} \mathrm{C}$ and $20 \mathrm{sec}$ at $60^{\circ} \mathrm{C}$, and finally 1 cycle of $15 \mathrm{sec}$ at $95^{\circ} \mathrm{C}, 1 \mathrm{~min}$ at $55^{\circ} \mathrm{C}$, and $15 \mathrm{sec}$ at $95^{\circ} \mathrm{C}$.

Table 1. The nucleotide sequences of the PCR primers used to assay gene expression by real-time quantitative PCR.

\begin{tabular}{|l|l|l|}
\hline Gene (species) & Forward & Reverse \\
\hline HPRT (Mouse) & 5'GCT TTC CCT GGT TAA GCA GTA CA3' & 5'CAA ACT TGT CTG GAA TTT CAA ATC3' \\
\hline $\boldsymbol{\beta}$-actin (Mouse) & 5'AGT GTG ACG TTG ACA TCC GT3' & 5'GCA GCT CAG TAA CAG TCC GC3' \\
\hline
\end{tabular}


Individual real-time quantitative PCR reactions were carried out in $10 \mu \mathrm{L}$ volumes deposited into a 384-well plate containing $5 \mu \mathrm{L}$ of SYBR Green PCR Master Mix (Applied Biosystems, Mulgrave, Vic, Australia), $4 \mu \mathrm{L}$ of RNase-free water, $0.5 \mu \mathrm{L}$ of $10 \mu \mathrm{M}$ sense and antisense PECAM-1 primers and $0.5 \mu \mathrm{L}$ of the cDNA template. Four biological and 3 technical replicates were performed for each sample. At the end of each run, cycle threshold (Ct) values were automatically determined using the ViiA 7 Software.

Gene expression was calculated using the $2^{-\Delta \Delta C t}$ method whereby the $\mathrm{Ct}$ values of the target transcripts were normalised to the $\mathrm{Ct}$ values of the house-keeping gene. Thus, all experimental samples are expressed as an $\mathrm{n}$-fold difference relative to the calibrator (48). Ct values of $>35$ cycles were interpreted as negative for gene expression.

\section{In-cell ELISA}

Cells in 96-well culture plates were fixed with $4 \%$ paraformaldehyde at $1,48,120$, or $168 \mathrm{~h}$ post-irradiation. At each time point, plates containing samples irradiated with different doses of 5, 15, and 25 Gy were assayed in triplicate. Non-irradiated plates were used as controls. After fixation, the wells were blocked with $4 \%$ Bovine Serum Albumin (Sigma-Aldrich) in $1 \times \mathrm{PBS}$ for $2 \mathrm{~h}$ on a plate shaker at $\sim 300 \mathrm{rpm}$. Mouse PECAM-1 ELISA kit (Biosensis, Thebarton, SA, Australia) was applied to samples according to the manufacturer's instructions. Primary PECAM-1 antibody was diluted to 1:99 with diluent buffer, and added to the sample for a $2 \mathrm{~h}$ incubation. After washing the plate, $90 \mu \mathrm{L}$ of warmed TMB colour developing agent was added. The reaction was terminated after $1 \mathrm{~h}$ by the addition of a stopping buffer. Absorbance was measured at $450 \mathrm{~nm}$ using PHERAstar FS (BMG Labtech, Cary, NC, USA). Duplicate wells containing no primary anti-PECAM-1 antibody were assayed for each sample and their average absorbance was subtracted from the average sample absorbance.

Determination of cell confluency was blinded and performed under light microscopy by two independent assessors. The final absorbance value was adjusted to include cell density by dividing the average absorbance by confluency.

\section{Statistics}

Data were analysed using multiple two-tailed unpaired t-tests in Microsoft Excel 2007 and GraphPad Prism Version 6 for real-time quantitative PCR and in-cell ELISA, comparing irradiated to control groups at each time point. A $p$ value of $\leq 0.05$ was considered statistically significant.

\section{RESULTS}

\section{Real-time quantitative PCR}

The specificities of the primers were confirmed using gel electrophoresis, which resulted in single products. Melting curves resulted in single products with specific melting temperatures indicating that the primer pairs were highly specific. No primer-dimers were generated during the applied 40 real-time PCR amplification cycles. All primer efficiencies, either obtained from the manufacturer or previously determined in our laboratory, range from $90-110 \%$.

Real-time quantitative PCR demonstrated statistically significant up-regulation of PECAM-1 genes in bEnd. 3 cells irradiated at 25 Gy relative to non-irradiated controls at all time points up to $168 \mathrm{~h}$ (figure 1). The maximum PECAM-1 gene expression in the irradiated group relative to the control group occurred at $120 \mathrm{~h}$ following 25 Gy irradiation. An 11-fold increase was documented at this time point $(\mathrm{p}<0.001)$.

Similarly, up-regulation of the PECAM-1 gene was observed in cells irradiated with 5 and 15 Gy (figure 1). PECAM-1 gene expression in the irradiated samples relative to control samples peaked at $120 \mathrm{~h}$. Cells irradiated at 15 and 5 Gy had a 2.8-fold ( $<<0.001$ ) and 1.8-fold $(\mathrm{p}<0.001)$ increase respectively at $120 \mathrm{~h}$ relative to control samples.

\section{In-cell ELISA}

As shown in table 2, the confluency of the cells was lower in the irradiated group in 
comparison to the non-irradiated group. Furthermore, the change in cell confluency was dose and time dependent. In order to compensate for the variation in cell numbers in the different wells when detecting the average PECAM-1 expression on cell surface, in-cell ELISA results were adjusted by the cell confluency in the corresponding wells.

In-cell ELISA results demonstrated significant up-regulation of PECAM-1 at 5, 15, and 25 Gy following radiation exposure (figure 2). Cells irradiated at 25 Gy showed up-regulation of PECAM- 1 at all time points, with the maximum level of expression at the last time point (168 h). At this time point, a mean difference of over 5 absorbance units (adjusted for confluency) was detected between irradiated and non-irradiated groups.

Subclinical doses of radiation of 15 and 5 Gy also induced significant PECAM-1 up-regulation at the later time points. Cells irradiated at 15 and 5 Gy had a maximum mean difference of 2.9 and 0.5 absorbance units respectively, relative to control samples. PECAM-1 protein expression
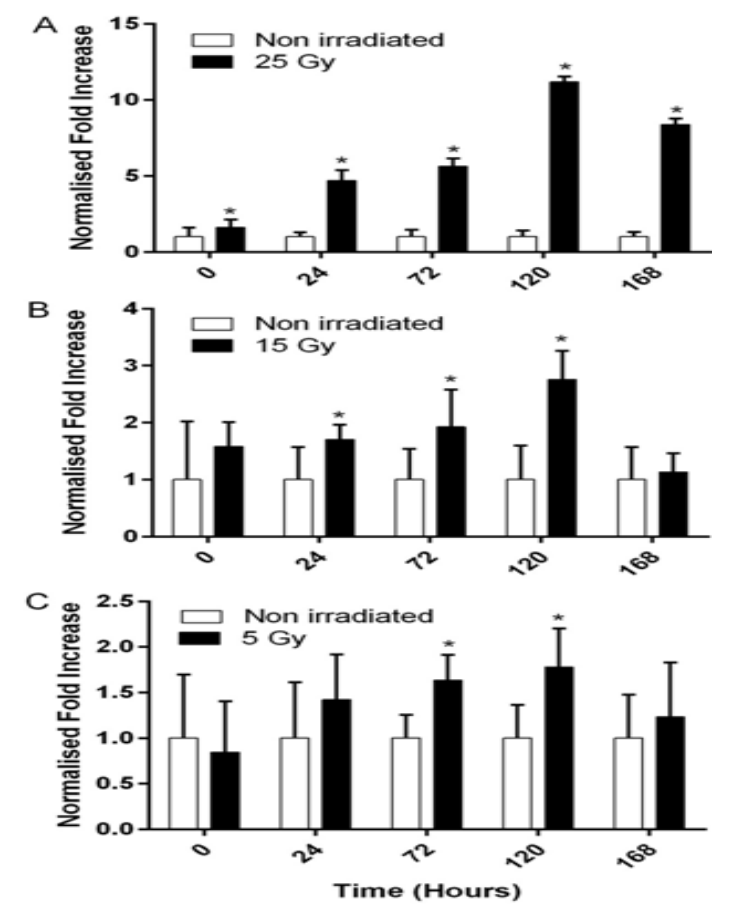

Figure 1. Relative PECAM-1 gene expression in bEnd. 3 cells between irradiated and control groups at 1, 24, 72, 120, and $168 \mathrm{~h}$ post-irradiation at a) $25 \mathrm{~Gy}$, b) $15 \mathrm{~Gy}$ and c) $5 \mathrm{~Gy}$ measured with real-time quantitative PCR $(n=12)$. Error bars denote standard deviation. on irradiated bEnd.3 cells reflects a similar pattern of up-regulation in comparison to its gene expression. Figure 2 demonstrates that the up-regulation of PECAM-1 relative to the control samples was more prominent at 120 and $168 \mathrm{~h}$ post-irradiation compared to earlier time points for all three radiation doses, which is similar to PECAM-1 gene expression. However, the peak in protein expression occurred later than that of gene expression in samples irradiated at 15 and 25 Gy. A temporal delay of at least $48 \mathrm{~h}$ was present between PECAM-1 gene expression and PECAM-1 surface protein expression.

Table 2. Average cell confluency at $1,48,120$, and $168 \mathrm{~h}$ post-irradiation after receiving $25 \mathrm{~Gy}, 15 \mathrm{~Gy}, 5 \mathrm{~Gy}$, or no radiation.

\begin{tabular}{|c|c|c|c|c|}
\hline \multirow{2}{*}{ Time (h) } & \multicolumn{4}{|c|}{ Cell confluency (\%) } \\
\cline { 2 - 5 } & $\mathbf{2 5}$ Gy & 15 Gy & 5 Gy & 0 Gy \\
\hline 1 & 40 & 40 & 40 & 40 \\
\hline 48 & 40 & 60 & 80 & 90 \\
\hline 120 & 30 & 50 & 80 & 100 \\
\hline 168 & 30 & 40 & 90 & 100 \\
\hline
\end{tabular}
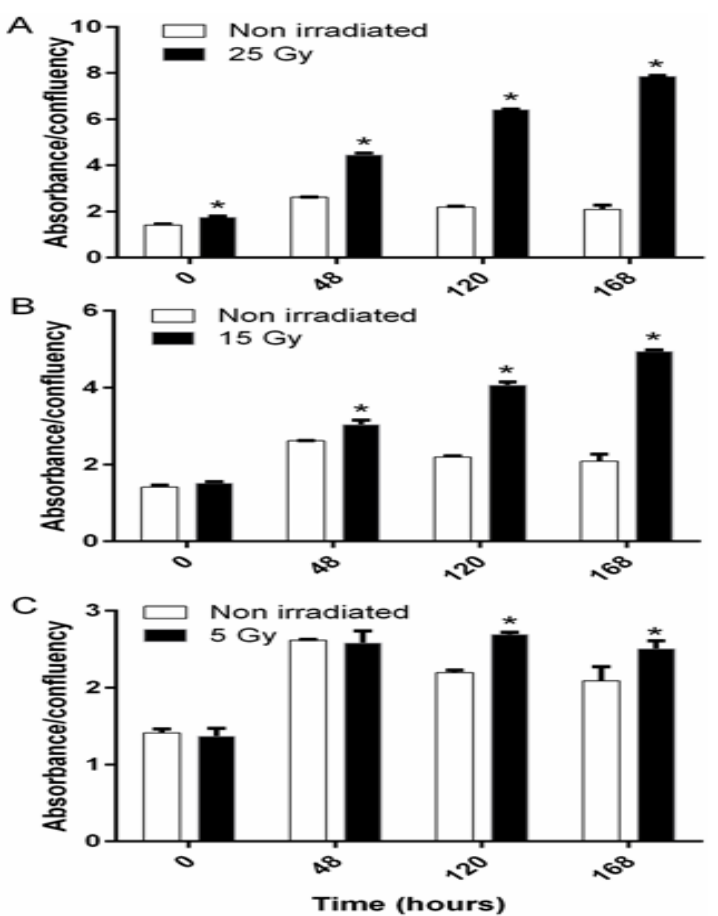

Figure 2. Surface PECAM-1 expression on bEnd. 3 cells between the irradiated groups a) $25 \mathrm{~Gy}$, b) $15 \mathrm{~Gy}$, and c) $5 \mathrm{~Gy}$ and the control group at $1,48,120$, and $168 \mathrm{~h}$ postirradiation measured with in-cell ELISA $(n=3)$. Error bars denote standard deviation.

Int. J. Radiat. Res., Vol. 14 No. 3, July 2016 


\section{DISCUSSION}

Currently, no AVM endothelial molecule has been reported to be adequately discriminating to allow for the application of vascular targeting in AVM treatment. The present study demonstrates the up-regulation of PECAM-1 on cerebral endothelium after irradiation, highlighting its potential as a vascular target.

Real-time quantitative PCR and in-cell ELISA demonstrated that PECAM-1 expression can be up-regulated by radiation. The effect of radiation is long-lasting, enhancing PECAM-1's expression up to 7 days following irradiation. Significant elevation in the level of PECAM-1 postirradiation in bEnd. 3 cells supports its use as a molecular target for vascular targeting, especially considering that over an 11-fold increase $(p<0.001)$ was observed 120 h postirradiation relative to control samples at $25 \mathrm{~Gy}$. Similarly, a maximum in mean difference of over 5 absorbance units (adjusted for confluency) between irradiated and control groups was observed in the in-cell ELISA.

AVM size is a vital limiting factor for the application of radiosurgery as a priming device for vascular targeting. However, if the radiation dose can be lowered, larger AVMs could be targeted. Even at doses of 5 and 15 Gy, both in vitro experiments showed that radiation was able to induce significant up-regulation of the PECAM -1 gene. Whilst this up-regulation is much less than samples irradiated at $25 \mathrm{~Gy}$, a 2.8-fold increase may be adequate for specific vascular targeting. Studies examining the effect of radiation dose between 15 and 25 Gy may be beneficial as the ideal radiation dose should be sufficiently low to minimise damage to the surrounding tissue but at the same time high enough to guarantee significant phenotype alteration on endothelial cells.

The in-cell ELISA results evaluating PECAM1's expression on bEnd.3 cells validate the PECAM-1 gene up-regulation observed in the real-time quantitative PCR. However, the peak protein expression in the irradiated samples occurred later than peak gene expression following radiosurgery. This was especially apparent in samples irradiated at 15 and 25 Gy where the peak for PECAM-1 gene expression occurred at $120 \mathrm{~h}$ post-irradiation but the maximum level of PECAM-1 protein expression was at $168 \mathrm{~h}$ post-irradiation and appeared to be still rising. The temporal delay in the correlation of mRNA and protein expression may reflect that time is required for translation and posttranslation modification following the completion of transcription (49).

The increase in PECAM-1 expression after irradiation is congruent with the majority of the current literature (38-41). However, Heckman et al. and Rhodes et al. demonstrated no difference in PECAM-1 expression between control and irradiated groups $(50,51)$. A possible explanation for the discordance is the differences in the type of endothelium and the time points studied after radiation exposure. Heckman etal. and Rhodes et al. examined PECAM-5 expression only up to 5 day after irradiation, at which point there might not have been a significant increase in PECAM-1 expression $(50,51)$.

The major limitation of this study is the lack of hemodynamic changes associated with an $\mathrm{AVM}$ and the interaction between endothelial cells and underlying smooth muscle. Moreover, mouse cerebral endothelial cells used in this study may display phenotypic differences to human cerebral endothelial cells when irradiated. Future experiments using animal models and human cerebral endothelial cells should be considered.

\section{CONCLUSION}

The results of this project demonstrate that radiosurgery can significantly alter endothelial cell phenotype in vitro with subclinical doses of radiation, potentially enabling the use of ligandbased molecular targeting therapies for AVM treatment. This study provides a platform upon which other endothelial surface molecules can be tested for suitability as a vascular target in AVM treatment. 


\section{ACKNOWLEDGMENT}

This project was supported by the National Health and Medical Research Council grant APP1047302 (primary investigator, Marcus Stoodley).

\section{Conflict of interest: Declared None.}

\section{REFERENCES}

1. Li L, Story M, and Legerski RJ (2001) Cellular responses to ionizing radiation damage. Int J Radiat Oncol Biol Phys, 49: 1157-62.

2. Rodemann HP and Blaese MA (2007) Responses of normal cells to ionizing radiation. Semin Radiat Oncol, 17: 81-8.

3. Brown KR and Rzucidlo E (2011) Acute and chronic radiation injury. J Vasc Surg, 53: 15S-21S.

4. Eriksson D and Stigbrand T (2010) Radiation-induced cell death mechanisms. Tumour Biol, 31: 363-72.

5. Zhao Z, Johnson M, Chen B, Grace M, Ukath J, and Lee V (2015) Live cell imaging to detect phosphatidylserine externalization in brain endothelial cells exposed to ionizing radiation: implications for the treatment of brain arteriovenous malformations. Journal of Neurosurgery In Press,

6. Lippitz B, Lindquist C, Paddick I, Peterson D, O'Neill K, and Beaney R (2014) Stereotactic radiosurgery in the treatment of brain metastases: the current evidence. Cancer Treat Rev, 40: 48-59.

7. Flickinger JC, Kano H, Niranjan A, Kondziolka D, and Lunsford LD (2013) Dose selection in stereotactic radiosurgery. Prog Neurol Surg, 27: 49-57.

8. Fajardo L, lonizing Radiation and the Endothelium, in Late Effects of Cancer Treatment on Normal Tissues, P. Rubin, et al., Editors. 2008, Springer: Berlin.

9. Reddy R, Duong TT, Fairhall JM, Smee RI, and Stoodley MA (2014) Durable thrombosis in a rat model of arteriovenous malformation treated with radiosurgery and vascular targeting. J Neurosurg, 120: 113-9.

10. Mohr JP, Grotta JC, Wolf P, Mayberg M, and Moskowitz M, Stroke: pathophysiology, diagnosis, and management. 3rd ed ed. 2011: Elsevier.

11. Al-Shahi R and Warlow C (2001) A systematic review of the frequency and prognosis of arteriovenous malformations of the brain in adults. Brain, 124: 1900-26.

12. Mohr JP (1999) Arteriovenous malformations of the brain in adults. N Engl J Med, 340: 1812-8.

13. Friedlander RM (2007) Arteriovenous Malformations of the Brain. N Engl J Med,356: 2704-2712.

14. da Costa L, Wallace MC, Ter Brugge KG, O'Kelly C, Willinsky RA, and Tymianski M (2009) The natural history and predictive features of hemorrhage from brain arteriovenous malformations. Stroke, 40: 100-5.

15. Berman MF, Sciacca RR, Pile-Spellman J, Stapf C, Connolly ES, Jr., Mohr JP, and Young WL (2000) The epidemiology of brain arteriovenous malformations. Neurosurgery, 47: 38996.

16. Brown RD, Jr., Wiebers DO, Torner JC, and O'Fallon WM (1996) Frequency of intracranial hemorrhage as a presenting symptom and subtype analysis: a populationbased study of intracranial vascular malformations in Olmsted Country, Minnesota. J Neurosurg, 85: 29-32.

17. Ondra SL, Troupp H, George ED, and Schwab K (1990) The natural history of symptomatic arteriovenous malformations of the brain: a 24-year follow-up assessment. J Neurosurg, 73: 387-91.

18. Spetzler RF and Martin NA (1986) A proposed grading system for arteriovenous malformations. J Neurosurg, 65: 476-83.

19. Han PP, Ponce FA, and Spetzler RF (2003) Intention-totreat analysis of Spetzler-Martin grades IV and V arteriovenous malformations: natural history and treatment paradigm. J Neurosurg, 98: 3-7.

20. Ferch RD and Morgan MK (2002) High-grade arteriovenous malformations and their management. J Clin Neurosci, 9: 37-40.

21. Starke RM, Komotar RJ, Hwang BY, Fischer LE, Garrett MC, Otten ML, and Connolly ES (2009) Treatment guidelines for cerebral arteriovenous malformation microsurgery. $\mathrm{Br} J$ Neurosurg, 23: 376-86.

22. Ogilvy CS, Stieg PE, Awad I, Brown RD, Jr., Kondziolka D, Rosenwasser R, Young WL, Hademenos G, and Special Writing Group of the Stroke Council ASA (2001) AHA Scientific Statement: Recommendations for the management of intracranial arteriovenous malformations: a statement for healthcare professionals from a special writing group of the Stroke Council, American Stroke Association. Stroke, 32: 1458-71.

23. Miyamoto S, Hashimoto N, Nagata I, Nozaki K, Morimoto M, Taki W, and Kikuchi H (2000) Posttreatment sequelae of palliatively treated cerebral arteriovenous malformations. Neurosurgery, 46: 589-94.

24. Wikholm G, Lundqvist C, and Svendsen P (2001) The Goteborg cohort of embolized cerebral arteriovenous malformations: a 6-year follow-up. Neurosurgery, 49: 799805.

25. Nataraj A, Mohamed MB, Gholkar A, Vivar R, Watkins L, Aspoas R, Gregson B, Mitchell P, and Mendelow AD (2013) Multimodality Treatment of Cerebral Arteriovenous Malformations. World Neurosurg, Vol?? page numbers???

26. Bradac O, Charvat F, and Benes V (2013) Treatment for brain arteriovenous malformation in the 1998-2011 period and review of the literature. Acta Neurochir (Wien), 155: 199-209.

27. Friedman WA, Bova FJ, Bollampally $S$, and Bradshaw $P$ (2003) Analysis of factors predictive of success or complications in arteriovenous malformation radiosurgery. Neurosurgery, 52: 296-307.

28. Yen CP, Schlesinger D, and Sheehan JP (2013) Natural 


\section{Chen et al. / Radiation-induced expression of PECAM-1}

history of cerebral arteriovenous malformations and the risk of hemorrhage after radiosurgery. Prog Neurol Surg, 27: 5-21.

29. Maruyama K, Kawahara N, Shin M, Tago M, Kishimoto J, Kurita H, Kawamoto S, Morita A, and Kirino T (2005) The risk of hemorrhage after radiosurgery for cerebral arteriovenous malformations. N Engl J Med, 352: 146-53.

30. Pollock BE, Flickinger JC, Lunsford LD, Bissonette DJ, and Kondziolka D (1996) Hemorrhage risk after stereotactic radiosurgery of cerebral arteriovenous malformations. Neurosurgery, 38: 652-9.

31. Karlsson B, Lindquist C, and Steiner L (1996) Effect of Gamma Knife surgery on the risk of rupture prior to AVM obliteration. Minim Invasive Neurosurg, 39: 21-7.

32. Steinberg GK, Fabrikant JI, Marks MP, Levy RP, Frankel KA, Phillips MH, Shuer LM, and Silverberg GD (1990) Stereotactic heavy-charged-particle Bragg-peak radiation for intracranial arteriovenous malformations. N Engl J Med, 323: 96-101.

33. Thorpe PE (2004) Vascular targeting agents as cancer therapeutics. Clin Cancer Res, 10: 415-27.

34. Storer KP, Tu J, Karunanayaka A, Morgan MK, and Stoodley MA (2007) Thrombotic molecule expression in cerebral vascular malformations. J Clin Neurosci, 14: 975-80.

35. Storer KP, Tu J, Karunanayaka A, Morgan MK, and Stoodley MA (2008) Inflammatory molecule expression in cerebral arteriovenous malformations. J Clin Neurosci, 15: 179-84.

36. Hashimoto T, Lawton MT, Wen G, Yang GY, Chaly T, Jr., Stewart CL, Dressman HK, Barbaro NM, Marchuk DA, and Young WL (2004) Gene microarray analysis of human brain arteriovenous malformations. Neurosurgery, 54: 410-23.

37. Matsubara S, Bourdeau A, terBrugge KG, Wallace $C$, and Letarte $M$ Analysis of endoglin expression in normal brain tissue and in cerebral arteriovenous malformations. Stroke, 31: 2653-60.

38. Quarmby S, Kumar P, Wang J, Macro JA, Hutchinson JJ, Hunter RD, and Kumar S (1999) Irradiation induces upregulation of CD31 in human endothelial cells. Arterioscler Thromb Vasc Biol, 19: 588-97.

39. Gaugler MH, Squiban C, Mouthon MA, Gourmelon P, and van der Meeren A (2001) Irradiation enhances the support of haemopoietic cell transmigration, proliferation and differentiation by endothelial cells. Br J Haematol, 113: 940-50.

40. Van der Meeren A, Vandamme M, Squiban C, Gaugler MH, and Mouthon MA (2003) Inflammatory reaction and changes in expression of coagulation proteins on lung endothelial cells after total-body irradiation in mice. Radiat Res, 160: 637-46.

41. Gaugler MH, Vereycken-Holler V, Squiban C, and Aigueperse J (2004) PECAM-1 (CD31) is required for interactions of platelets with endothelial cells after irradiation. J Thromb Haemost, 2: 2020-6.

42. Favaloro EJ, Moraitis N, Koutts J, Exner T, and Bradstock KF (1989) Endothelial cells and normal circulating haemopoietic cells share a number of surface antigens. Thromb Haemost, 61: 217-24.

43. Newman PJ and Newman DK (2003) Signal transduction pathways mediated by PECAM-1: new roles for an old molecule in platelet and vascular cell biology. Arterioscler Thromb Vasc Biol, 23: 953-64.

44. Muller WA, Weigl SA, Deng $X$, and Phillips DM (1993) PECAM-1 is required for transendothelial migration of leukocytes. J Exp Med, 178: 449-60.

45. Schimmenti LA, Yan HC, Madri JA, and Albelda SM (1992) Platelet endothelial cell adhesion molecule, PECAM-1, modulates cell migration. J Cell Physiol, 153: 417-28.

46. Simonian M, Molloy MP, and Stoodley MA (2012) In vitro and in vivo biotinylation of endothelial cell surface proteins in the pursuit of targets for molecular therapies for brain AVMs. Metabolomics, 007-1-007-4.

47. Albelda SM, Muller WA, Buck CA, and Newman PJ (1991) Molecular and cellular properties of PECAM-1 (endoCAM/ CD31): a novel vascular cell-cell adhesion molecule. J Cell Biol, 114: 1059-68.

48. Livak KJ and Schmittgen TD (2001) Analysis of relative gene expression data using real-time quantitative PCR and the 2 (-Delta Delta C(T)) Method. Methods, 25: 402-8.

49. Fournier ML, Paulson A, Pavelka N, Mosley AL, Gaudenz K, Bradford WD, Glynn E, Li H, Sardiu ME, Fleharty B, Seidel C, Florens L, and Washburn MP (2010) Delayed correlation of mRNA and protein expression in rapamycin-treated cells and a role for Ggc1 in cellular sensitivity to rapamycin. $\mathrm{Mol}$ Cell Proteomics, 9: 271-84.

50. Rhodes LE, Joyce M, West DC, Strickland I, and Friedmann PS (1996) Comparison of changes in endothelial adhesion molecule expression following UVB irradiation of skin and a human dermal microvascular cell line (HMEC-1). Photodermatol Photoimmunol Photomed, 12: 114-21.

51. Heckmann M, Douwes K, Peter R, and Degitz K (1998) Vascular activation of adhesion molecule mRNA and cell surface expression by ionizing radiation. Exp Cell Res, 238:148-54. 